\title{
Are dietary habits of the Polish population consistent with the recommendations for prevention of cardiovascular disease? — WOBASZ II project
}

\author{
Anna Waśkiewicz ${ }^{1}$, Danuta Szcześniewska', Dorota Szostak-Węgierek ${ }^{2}$, Magdalena Kwaśniewska ${ }^{3}$, \\ Andrzej Pająk ${ }^{4}$, Urszula Stepaniak ${ }^{4}$, Krystyna Kozakiewicz ${ }^{5}$, Andrzej Tykarski ${ }^{6}$, Tomasz Zdrojewski ${ }^{7}$, \\ Małgorzata E. Zujko8, Wojciech Drygas ${ }^{1,3}$ \\ 'Department of Epidemiology, Cardiovascular Disease Prevention, and Health Promotion, National Institute of Cardiology, Warsaw, Poland \\ ${ }^{2}$ Department of Human Nutrition, Medical University of Warsaw, Warsaw, Poland \\ ${ }^{3}$ Department of Social and Preventive Medicine, Medical University of Lodz, Lodz, Poland \\ ${ }^{4}$ Department of Epidemiology and Population Studies, Institute of Public Health, Jagiellonian University Medical College, Krakow, Poland \\ ${ }^{5} 3^{\text {rd }}$ Department of Cardiology, Upper Silesian Centre of Cardiology, Medical University of Silesia, Katowice, Poland \\ ${ }^{6}$ Department of Hypertension, Angiology, and Internal Medicine, University of Medical Sciences, Poznan, Poland \\ ${ }^{7}$ Department of Prevention and Education, Department of Hypertension and Diabetology, Medical University of Gdansk, Gdansk, Poland \\ ${ }^{8}$ Department of Food Commodities Science and Technology, Medical University, Bialystok, Poland
}

\begin{abstract}
A b stract
Background: Diet is a modifiable risk factor for cardiovascular disease (CVD).

Aim: To assess diet quality in the adult Polish population, taking into consideration consumption of various nutrients as well as the total diet quality.

Methods: Within the frame of the National Multicentre Health Survey (WOBASZ II), a random sample of the whole Polish population aged 20 years and above was screened during the years 2013-2014. Dietary habits were assessed in 5690 subjects (2554 men and 3136 women). Nutrient intakes were compared to the Dietary Reference Intakes. Total diet quality was measured using the Healthy Diet Indicator (HDI) score, based on the World Health Organisation recommendations for CVD prevention, that includes 7 nutrients (saturated and polyunsaturated fatty acids, cholesterol, protein, dietary fibre, fruits and vegetables, free sugars) and ranges from 0 (the least healthy diet) to 7 (the healthiest diet).

Results: The studied group was characterised by a high prevalence of overweight and obesity $(69 \%$ in men vs. $59 \%$ in women), hypercholesterolaemia ( $56 \%$ vs. $55 \%$, respectively), hypertension ( $50 \%$ vs. $42 \%)$, and diabetes ( $12 \%$ vs. $10 \%)$. At the same time, a significant percentage of Poles had improper dietary habits. A low fat and low cholesterol diet was reported by only $8 \%$ and a low calorie diet by $1 \%$ of the respondents. Adding salt to already seasoned dishes was reported by $27 \%$ of men and $18 \%$ of women, and $56 \%$ and $30 \%$ of them, respectively, consumed meat products with visible fat. The diet of most adult Polish citizens was found to be not balanced. Vitamins A, C, E, B1, B2, B6, and B12, protein, dietary cholesterol and fruits/vegetables were consumed in recommended doses only by $44-80 \%$ of the respondents. The recommended intake of fat, saturated and polyunsaturated fatty acids, which significantly affect lipid levels, was found in 18-37\% of the respondents. Dietary intakes of folate and minerals important for the prevention of hypertension were insufficient. The desired level of folate intake was found only in $13-26 \%$ of the respondents, and that of magnesium, calcium and potassium in $5-36 \%$ of them. The average HDI value was about 3.2 (out of the maximum of 7). A healthy diet (5-7 points) was noted in $15 \%$ of adult Poles. Most subjects $(60 \%)$ were characterised by a low quality diet ( $0-3$ points). Nevertheless, about $55 \%$ of respondents believed that their diet was appropriate.

Conclusions: The quality of dietary habits of the majority of the adult Polish population falls far short of the recommendations relevant for CVD prevention.

Key words: dietary habits, diet, Polish general population, prevention of cardiovascular disease
\end{abstract}

Kardiol Pol 2016; 74, 9: 969-977

Address for correspondence:

Anna Waśkiewicz, MD, PhD, Department of Epidemiology, Cardiovascular Disease Prevention, and Health Promotion, National Institute of Cardiology, ul. Alpejska 42, 04-628 Warszawa, Poland, e-mail: awaskiewicz@ikard.pl

Received: 14.10.2015 Accepted: 15.12.2015 Available as AoP: 07.01.2016

Kardiologia Polska Copyright (C) Polskie Towarzystwo Kardiologiczne 2016 


\section{INTRODUCTION}

Proper diet is an important component in the prevention of cardiovascular disease (CVD) and other chronic non-infectious diseases. Nutrients of interest in the context of CVD prevention include fatty acids, some vitamins and minerals, and fibre. Indexes that evaluate global value of the diet are also important. Detailed relations between diet quality and CVD, at the level of both individual nutrients and whole diets, have been summarised in numerous publications [1-12].

According to the Joint Task Force of the European Society of Cardiology and Other Societies on Cardiovascular Prevention Disease in Clinical Practice, a challenge in the years to come will be to find ways to persuade societies to change their inappropriate dietary habits [13]. This requires developing diets that will comply with the guidelines and at the same time be attractive for consumers, and also encouraging the industry to produce foods of the desired composition.

However, to make efforts to popularise proper dietary habits, we first need to evaluate the current diet of the country's population to determine directions of necessary change. Such an opportunity was created by the Second National Multicentre Health Survey (Drugie Wieloośrodkowe Badanie Stanu Zdrowia Ludności [WOBASZ II]) that covered the whole country and was based on standardised methodology.

The aim of the study was to assess diet quality in the adult Polish population, taking into consideration consumption of various nutrients as well as the total diet quality.

\section{METHODS}

We analysed data collected during the WOBASZ II study, a research project undertaken in 2013-2014 by the National Institute of Cardiology in Warsaw in cooperation with 5 medical universities in Poland. The study included a random sample of the whole Polish population aged 20 years and above. A two-step sample selection procedure involved random selection of 6 communes in each of 16 provinces (voivodships), including 2 small communes (up to 8000 inhabitants), 2 medium-size communes (8000-40,000 inhabitants), and 2 large communes (over 40,000 inhabitants), plus the province capital (unless it was selected as one of the communes), followed by random selection of 70 men and 70 women in each commune. Overall, 108 communes were randomly selected, yielding overall 15,120 subjects (including 1657 respondents who were unavailable). Sampling frame included all subjects at the age specified in the selection criteria who were registered as permanent inhabitants of a given commune. For this purpose, the Common Electronic System of Population Register (Powszechny Elektroniczny System Ewidencji Ludności [PESEL]) database was used, run by the Department of State Registries of the Ministry of the Interior. Overall, 6170 respondents replied in the whole country, yielding the response rate of $45.6 \%$. Due to this low response rate in the WOBASZ II study, additional statistical analyses were performed that confirmed similar age distribution in the general Polish population and the study group, thus indicating that the WOBASZ II study was indeed representative for the general Polish population.

Detailed information on the methods used, approaches to data collection and measurements, and response rates in the WOBASZ II study were presented and discussed in a previous publication [14].

The final analysis of dietary habits included 5690 respondents (2554 men and 3136 women), after some subjects were excluded due to missing or unreliable diet histories. The mean age was 49.3 years in men and 50.7 years in women, with $34.1 \%$ of men and $31.3 \%$ of women in the age range $20-40$ years, $38.0 \%$ of men and $39.4 \%$ of women in the age range $41-60$ years, and $27.9 \%$ of men and $29.3 \%$ of women in the age range above 60 years.

Diet was evaluated by a trained pollster using a questionnaire that included food consumed during the last $24 \mathrm{~h}$. A portfolio with photographs of various food portion sizes was used to allow precise estimation of the quantities consumed. Information was also collected on dietary habits (use of special diets, adding salt and removing fat) and use of dietary supplements. Based on the information collected, energy content and nutritional value of the diet were calculated using the Polish tables of food composition and nutritional value [15]. In case of vitamins and minerals, their intake in both foods and dietary supplements was taken into account. Based on the collected data, the proportion of subjects achieving recommended nutrient intakes was calculated in reference to Estimated Average Requirement (EAR) values, and for some nutrients Adequate Intake (AI) values [16] and the World Health Organisation (WHO) recommendations [17].

To illustrate concordance with the WHO recommendations for CVD prevention, the Healthy Diet Indicator (HDI) score was calculated that includes 7 nutrients, with 1 point awarded for a recommended intake of a given nutrient, and 0 points if intake was not consistent with the recommendations. The maximum score for optimal diet was 7 points (Table 1) [18].

A wide range of conventional CVD risk factors was evaluated in WOBASZ II study participants using questionnaires, laboratory testing, and anthropometric measurements. Body mass index (BMI, $\mathrm{kg} / \mathrm{m}^{2}$ ) was calculated based on height and weight measurements. Fasting blood glucose and lipid profile was measured. Blood pressure was measured three times, with the mean value calculated from the second and third measurement.

\section{Statistical analysis}

The results were subjected to a statistical analysis using the Statistical Analysis System (SAS) software, version 9.2. Continuous variables were summarized using descriptive statistics (mean, standard deviation, median). 
Table 1. Scoring of the diet components for the Healthy Diet Indicator (HDI) score [18]

\begin{tabular}{lcc|} 
Diet component & Score 0 & Score 1 \\
\hline Saturated fatty acids (\% of calories) & $\geq 10$ & $<10$ \\
Polyunsaturated fatty acids (\% of calories) & $<6$ or $>10$ & $6-10$ \\
Cholesterol [mg/day] & $\geq 300$ & $<300$ \\
Protein (\% of calories) & $<10$ or $>15$ & $10-15$ \\
Dietary fibre [g/day] & $<25$ & $\geq 25$ \\
Fruits and vegetables [g/day] & $\geq 400$ & $\geq 400$ \\
Sugar (\% of calories) & Minimum 0 & Maximum 7 \\
Overall score & & \\
\hline
\end{tabular}

Table 2. Rates of selected cardiovascular disease risk factors in the respondents*

\begin{tabular}{|c|c|c|}
\hline Risk factor & Men & Women \\
\hline Hypercholesterolaemia (cholesterol $\geq 5 \mathrm{mmol} / \mathrm{L}$ ) & $55.5 \%$ & $55.3 \%$ \\
\hline Elevated LDL-C (LDL-C $\geq 3 \mathrm{mmol} / \mathrm{L})$ & $56.5 \%$ & $50.8 \%$ \\
\hline Low HDL-C (HDL-C $<1.0 \mathrm{mmol} / \mathrm{L}$ in men, $<1.2 \mathrm{mmol} / \mathrm{L}$ in women) & $18.7 \%$ & $20.8 \%$ \\
\hline Hypertension ${ }^{1}$ & $49.6 \%$ & $41.7 \%$ \\
\hline Hypertriglyceridaemia (TG > $1.7 \mathrm{mmol} / \mathrm{L}$ ) & $36.0 \%$ & $22.1 \%$ \\
\hline Diabetes $^{2}$ & $11.6 \%$ & $9.6 \%$ \\
\hline Overweight $\left(25 \mathrm{~kg} / \mathrm{m}^{2} \leq \mathrm{BMI}<30 \mathrm{~kg} / \mathrm{m}^{2}\right)$ & $43.9 \%$ & $31.8 \%$ \\
\hline Obesity (BMI $\geq 30 \mathrm{~kg} / \mathrm{m}^{2}$ ) & $25.1 \%$ & $27.2 \%$ \\
\hline
\end{tabular}

*Raw proportions (not standardised for age) in those subjects in whom dietary patterns were evaluated; ' $5 y s$ tolic blood pressure $\geq 140 \mathrm{~mm} \mathrm{Hg}$ and/or diastolic blood pressure $\geq 90 \mathrm{~mm} \mathrm{Hg}$ and/or use of antihypertensive drugs; ${ }^{2}$ Blood glucose $\geq 7 \mathrm{mmol} / \mathrm{L}$ and/or a history of diabetes; BMI body mass index; HDL-C — high density lipoprotein cholesterol; LDL-C — low density lipoprotein cholesterol; TG — triglycerides

Table 3. Prevalence of selected dietary habits in the adult Polish population

\begin{tabular}{|lcc|} 
Dietary habit & Men & Women \\
\hline Regularly adding salt to already seasoned dishes & $26.7 \%$ & $18.4 \%$ \\
Consuming meat products with visible fat or poultry with fatty skin & $55.7 \%$ & $29.5 \%$ \\
Adhering to a low fat, low cholesterol, or a diabetic diet & $7.1 \%$ & $8.0 \%$ \\
Adhering to a low calorie diet & $0.9 \%$ & $1.3 \%$ \\
Considering one's own diet appropriate & $53.8 \%$ & $55.3 \%$ \\
\hline
\end{tabular}

\section{RESULTS}

In the studied Polish population, we found high rates of CVD risk factors related to unhealthy diet (Table 2). The most common risk factors included elevated BMI and dyslipidaemia. More than half of the study population was characterised by excessive body weight and abnormal total cholesterol and low-density lipoprotein cholesterol (LDL-C) levels. The proportion of subjects with hypertension and diabetes was also relatively high.

Dietary habits of adult Poles were also much below the expected standards (Table 3). A low fat and low cholesterol diet or a diabetic diet was adhered to by 1 in 13 respondents, and a low calorie diet by 1 in 110 men and 1 in 77 women. Adding salt to already seasoned dishes was reported by $27 \%$ of men and $18 \%$ of women, and $56 \%$ and $30 \%$ of them, respectively, consumed meat products with visible fat or poultry with fatty skin. However, about 55\% of respondents believed that their diet was appropriate.

The diet of the adult Polish population was found to be not balanced in regard to the intake of some nutrients (Table 4). Relatively best adherence to the recommendations was found for antioxidant vitamins (A, C, E), most group $B$ vitamins (except folate), protein, fruits and vegetables in both genders, and dietary cholesterol in women. The mean 


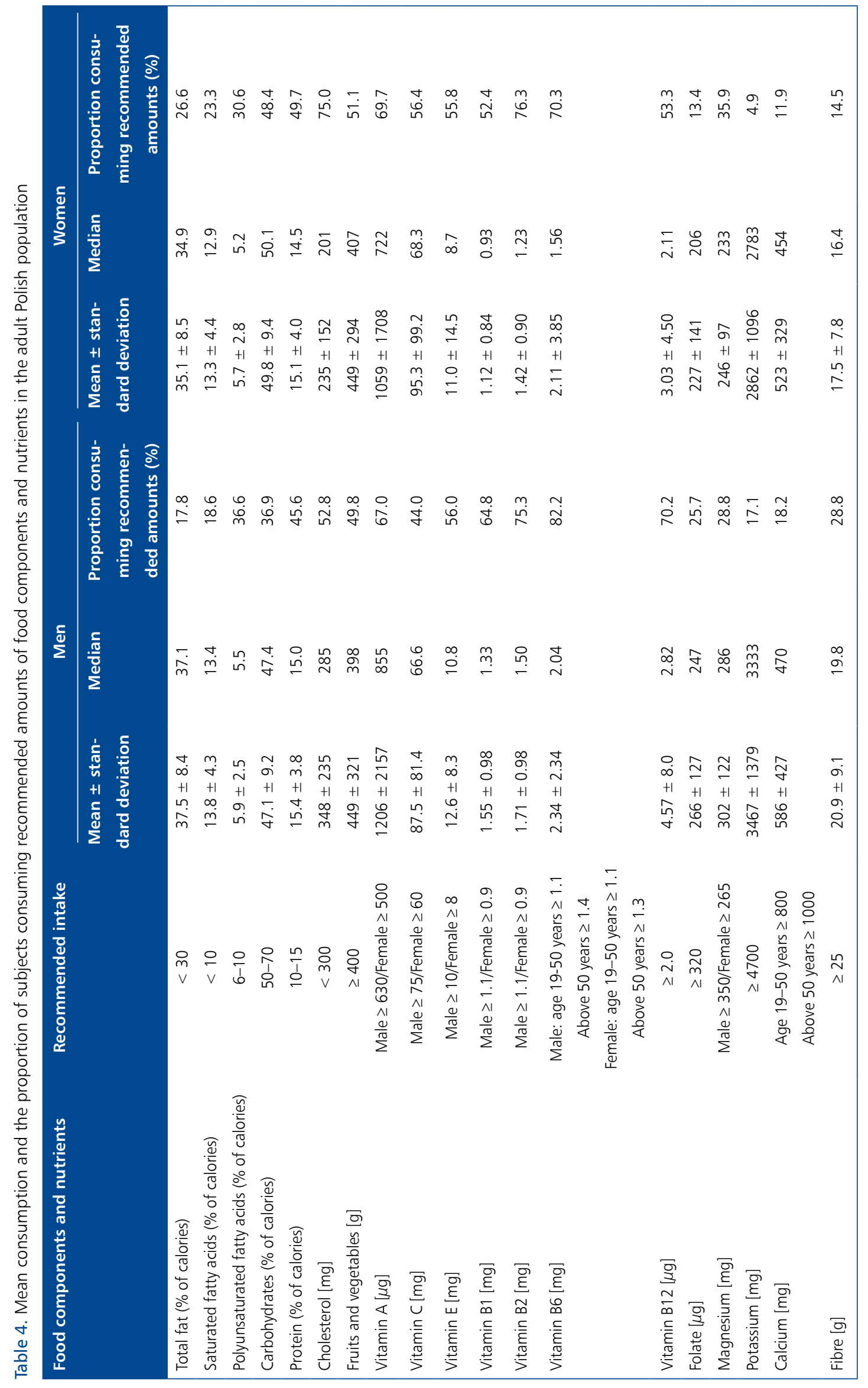


intake of these nutrients was close to the recommended values, although they were consumed in recommended doses only by $44-80 \%$ of the respondents.

Much worse results were obtained for overall fat and saturated fatty acids which were consumed in excessive amount, contributing to high atherogenicity of the average diet. The recommended intake of these fats was found in only small proportion of the respondents (below 20\% among men and below $30 \%$ among women).

Other nutrients of interest in the context of their effect CVD risk are minerals such as magnesium, potassium, and calcium. Unfortunately, their intake in the average diet was very low, particularly in case of calcium and potassium. Recommended intake of these minerals were noted in less than $20 \%$ of the respondents. Somewhat better results were obtained for magnesium, but the recommended intake was again noted in only about $30 \%$ of the respondents. The adult Polish population was also characterised by deficient folate and fibre intake, with low values of both the average intake and the proportion of respondents consuming the recommended amounts ( $26 \%$ of men and $13 \%$ of women).

In our study, we used the HDI score to evaluate dietary patterns predictive for the occurrence of civilisation diseases. Based on the mean values and the distribution of the HDI score, it can be concluded that the diet quality was significantly inappropriate in adult Poles (Table 5), with the average HDI value of 3.19 in men and 3.26 in women (out of the maximum of 7 ). Using this criterion, more than $60 \%$ of the respondents were characterised by a low quality diet ( $0-3$ points), and the recommended diet quality (5-7 points) was noted in only $15 \%$ of the respondents.

\section{DISCUSSION}

Nutrition is one of the major factors affecting cardiovascular risk not only directly but also through its effect on body mass, total and LDL-C levels, blood pressure, and the risk of diabetes. Of note, high rates of these risk factors were found in the studied sample of the Polish adult population. A high proportion of obese subjects and an increasing rate of obesity are of particular concern, as excessive body weight is known to be associated with higher rates of other risk factors for civilisation disease. In 2014, the proportion of obese subjects in the study population was above $25 \%$ compared to $21-22 \%$ a decade ago [19]. In the 2011 NATPOL study, obesity was found in $22 \%$ of adult Poles (unpublished data). Our study findings also showed that despite problems with excessive body weight, adherence to a low calorie diet was declared by only about $1 \%$ of the respondents.

High rates of hypercholesterolaemia and elevated LDL-C level may be due to inappropriate diet. It should be stressed that for maintaining normal blood cholesterol level and CVD risk reduction, it is highly important not only to reduce intake of saturated fatty acids but also replace them with
Table 5. Mean values and the distribution of the Healthy Diet Indicator (HDI) score in the adult Polish population

\begin{tabular}{|lcc|}
\hline Score & Men & Women \\
\hline Mean score & $3.19 \pm 1.31$ & $3.26 \pm 1.22$ \\
$0-3$ points & $60.5 \%$ & $60.2 \%$ \\
4 points & $24.2 \%$ & $24.4 \%$ \\
5-7 points & $15.3 \%$ & $15.4 \%$ \\
\hline
\end{tabular}

unsaturated fatty acids, particularly polyunsaturated ones [20]. It has been estimated based on epidemiological and clinical study findings that CVD is reduced by $2-3 \%$ with each $1 \%$ of the calorie intake from saturated fats is replaced with polyunsaturated fatty acids [3]. In the WOBASZ II study population, more than half of men and nearly one third of women consumed meat products with visible fat or poultry with fatty skin. Excessive total fat and saturated fatty acid intake was found in nearly $75-80 \%$ of the respondents, and the average intake of these food components was much above the recommended values. At the same, recommended intake of polyunsaturated fatty acids was reported by only $30-35 \%$ of the respondents. Thus, inappropriate intake of these two groups of fatty acids may be a factor underlying a high rate of hypercholesterolaemia in the Polish population. Excessive consumption of dietary cholesterol was found in a smaller proportion of the population (about $50 \%$ of men and $25 \%$ of women). Of other dietary factors affecting blood cholesterol levels, low fibre intake by more than $70 \%$ of men and about $85 \%$ of women should be noted.

On the other hand, no major differences in average intake of saturated and unsaturated fats, cholesterol, and fibre in the adult Polish population were noted over the last decade [19]. Thus, it seems that a reduction in the rates of hypercholesterolaemia and elevated LDL-C level seen in that period has been associated not with improved nutrition but with increasing use of lipid-lowering drugs (by about 50\% in men and nearly twofold in women).

Compared with the rates of hypercholesterolaemia, the prevalence of low high-density lipoprotein level was relatively low (19-20\%) and reduced by 1.3 and 5.2 percentage points in men and women, respectively, compared to a previous study a decade ago. It may be speculated, however, that this effect was related not to better nutrition but rather an increase in alcohol consumption in the Polish population (during this period, ethanol consumption increased by $8.5 \%$ in men and about $39 \%$ in women). This was confirmed by data published in 2012 by the National Institute of Hygiene [21].

The observed high prevalence of hypertension may also be affected by inappropriate nutrition in addition to the effect of excessive body weight. One in 4 men and one in 5 women reported regularly adding salt to already seasoned dishes. Low intake of minerals important for prevention of hypertension 
including calcium, potassium, and magnesium was also noted. In particular, potassium intake was inadequate in more than $80 \%$ of men and about $95 \%$ of women, which was related to low intake of fruits and vegetables. Consuming less than $400 \mathrm{~g}$ of fruits and vegetables per day, which is a recommended level, was reported by about $50 \%$ of the respondents of both genders. Fruits and vegetables are an important source of not only minerals but also vitamins, fibre, and flavonoids. Each additional portion of fruits and vegetables per day reduces the risk of a cardiovascular event by $4 \%$ and stroke by $5 \%$ [1]. Of note, the mean population intake of the above minerals did not change significantly over the last decade, while the mean intake of fruits and vegetables increased by about $50 \mathrm{~g}$ per day [19].

Antioxidant vitamins ( $A, C$ and $E$ ) that prevent oxidative modification of LDL particles and vitamins participating in homocysteine metabolism (folate, vitamins B6 and B12) are also necessary components of the healthy diet in the context of CVD risk reduction [22, 23]. It should be noted, however, that natural products should serve as the source of these vitamins, as supplementation with high doses that largely exceeded body requirements for these nutrients had no effect on the cardiovascular event risk [22]. Our findings indicate that the mean intake of antioxidant vitamins in the adult Polish population was within the recommended values but individual intake was inadequate in nearly half of the respondents. Intake of vitamins preventing hyperhomocysteinaemia was also inadequate in many subjects, particularly in regard to folate intake which was too low in about $75 \%$ of men and $85 \%$ of women.

Evaluation of diet by comparing intake of particular nutrients to the reference values gives only a partial measure of the overall diet quality. Therefore, in our study we also used the HDI score which has been used in epidemiological studies for the comprehensive evaluation of diet and its relation to health (Table 1). Of note, in the EPIC-NL cohort that included more than 33,000 subjects aged 20-70 years, higher HDI score values were associated with longer living in good health [18]. In another study that analysed data from prospective follow-up of 11 cohorts with nearly 400,000 respondents, overall diet quality was evaluated using a score of up to 70 points. Higher scores using that scale were found to be associated with prolonged survival (by mean 2 years) [24]. Similar observation in the Eastern European population showed an inverse association between HDI scores and CVD and coronary artery disease mortality, with no association with mortality due to other causes [25].

Our findings indicate the recommended diet quality (5-7 points) in only about $15 \%$ of adult Poles, while most of the respondents (about 60\%) were characterised by a low quality diet (0-3 points). The mean HDI score was 3.2 in men and 3.3 in women. Similar results were reported in the study by Haveman-Nies et al. [26] in the populations of Framingham (USA), Padua (Italy) and Betanzos (Spain), with HDI scores in the range of 3.3-3.4. In other populations in this study, including Hamme (Belgium), Roskilde (Denmark), Burgdorf (Switzerland), Culemborg (The Netherlands), and elderly subjects in the Warsaw area, HDI scores were even lower, in the range of 2.6-2.9 [26, 27]. In the latter study, nearly $70 \%$ of the seniors in the Warsaw area were characterised by a poor quality diet. Better results were obtained in the elderly subjects in the United Stated in the study by Sahyoun et al. [28] who evaluated diet quality using the Healthy Eating Index (HEI).

It should be noted that HDI score values may differ between hypertensives and normotensives. In a Japanese study [29] patients with untreated hypertension were characterised by significantly lower HDI score values compared to those without hypertension (4.12 \pm 1.24 vs. $4.59 \pm 1.16$, respectively). With low HDI score values the odds ratio of untreated hypertension (adjusted for other factors) was 3.05 (95\% confidence interval 1.25-7.40, $p=0.014)$. In the WOBASZ II study, we found no significant difference in the mean HDI score values between hypertensives and normotensives.

In summary, despite the fact that nutrition is a modifiable risk factor, the quality of dietary habits of the majority of the adult Polish population falls far short of the recommendations relevant for CVD prevention, including the Polish Forum for Prevention recommendations [30]. In addition, most inhabitants of our country believe that their diet is appropriate.

\section{CONCLUSIONS}

1. A significant proportion of the adult Polish population is characterised by inappropriate dietary habits.

2. The majority of the adult Polish population consumes saturated and polyunsaturated fatty acids and fibre in amounts that are not consistent with the recommendations.

3. Half of the adult Polish population consumes inadequate amounts of fruits and vegetables.

4. Intake of vitamins important for CVD prevention, particularly folate, is inadequate in a significant proportion of the adult Polish population.

5. Insufficient intake of minerals important for the prevention of hypertension was found in a significant proportion of the adult Polish population.

6. The quality of dietary habits of the majority of the adult Polish population falls far short of the WHO recommendations.

The WOBASZ II study was supported by the Polish Ministry of Health under the 2010-2012 National Program for the Equal Access to CVD Prevention and Treatment (POLKARD), task: Analyses and Epidemiology — Monitoring of CVD epidemiology in Poland.

Conflict of interest: none declared 


\section{References}

1. European Heart Network. Diet, Physical Activity and Cardiovascular Disease Prevention in Europe, 2011.

2. $\mathrm{Hu}$ FB. Diet and lifestyle influences on risk of coronary heart disease. Curr Atheroscler Rep, 2009; 11: 257-263.

3. Astrup A, Dyerberg J, Elwood P et al. The role of reducing intakes of saturated fat in the prevention of cardiovascular disease: where does the evidence stand in 2010? Am J Clin Nutr, 2011; 93: 684-668. doi: 10.3945/ajcn.110.004622.

4. Jacobsen MU, O’Reilly EJ, Heitmann BL et al. Major types of dietary fat and risk of coronary heart disease: a pooled analysis of 11 cohort studies. Am J Clin Nutr, 2009; 89: 1425-1432. doi: 10.3945/ajcn.2008.27124.

5. Skeaff C, Miller J. Dietary fat and coronary heart disease: summary of evidence from prospective cohort and randomised controlled trials. Ann Nutr Metab, 2009; 55: 173-201. doi: 10.1159/000229002.

6. Siri-Tarino PW, Sun Q, HFB et al. Saturated fat, carbohydrate and cardiovascular disease. Am J Clin Nutr, 2010; 91: 502-509. doi: 10.3945/ajcn.2008.26285.

7. Siri-Tarino PW, Sun Q, HFB at al. Meta-analysis of prospective cohort studies evaluating the association of saturated fat with cardiovascular disease. Am J Clin Nutr, 2010; 91: 535-546. doi: 10.3945/ajcn.2009.27725.

8. Stamler J. Diet-heart: a problematic revisit. Am J Clin Nutr, 2010 91: 497-499. doi: 10.3945/ajcn.2010.29216.

9. Szostak-Wegierek D, Kłosiewicz-Latoszek L, Szostak WB, et al. The role of dietary fats for preventing cardiovascular diseases. A review. Rocz Panstw Zakl Hig, 2013; 64: 263-269.

10. Kłosiewicz-Latoszek L. Zalecenia żywieniowe w prewencji chorób przewlekłych. Probl Hig Epidemiol, 2009; 90: 447-450.

11. Zhan J, Liu YJ, Cai LB et al. Fruit and vegetable consumption and risk of cardiovascular disease: a meta-analysis of prospective cohort studies. Crit Rev Food Sci Nutr, 2015; Ahead of print. doi: 10.1080/10408398.2015.1008980.

12. Gil A, Victoria EM, Olza J. Indicators for the evaluation of diet quality. Nutr Hosp, 2015; 31 (suppl. 3): 128-144. doi: 10.3305/nh.2015.31.sup3.8761.

13. Piąta Wspólna Grupa Robocza Europejskiego Towarzystwa Kardiologicznego i Innych Towarzystw Naukowych ds. Zapobiegania Chorobom Serca i Naczyń w Praktyce Klinicznej. Europejskie wytyczne dotyczące zapobiegania chorobom serca i naczyń w praktyce klinicznej. Kardiol Pol, 2012; 70 (suppl 1): $1-100$.

14. Drygas W, Niklas A, Piwońska A et al. Wieloośrodkowe Ogólnopolskie Badanie Stanu Zdrowia Ludności (Badanie WOBASZ II): założenia, metody i realizacja. Kardiol Pol, 74: 2016; 681-690. doi: 10.5603/KP.a2015.0235.

15. Kunachowicz H, Nadolna I, Przygoda B et al. Tabele składu i wartości odżywczej żywności. PZWL, Warszawa 2005 (wydanie rozszerzone i uaktualnione, wersja elektroniczna 2011).

16. Jarosz M. Normy żywienia dla populacji polskiej — nowelizacja (The Polish dietary standards- amendments). Wydawnictwo İ்̇̇, Warszawa 2012
17. Report of a Joint WHO/FAO Expert Consultation. Diet, nutrition and the prevention of chronic diseases. WHO Technical Report Series 916. WHO, Geneva 2003.

18. Fransen HP, Beulens JW, May AM et al. Dietary patterns in relation to quality-adjusted life years in the EPIC-NL kohort. Prev Med, 2015; 77: 119-124. doi: 10.1016/j.ypmed.2015.05.014.

19. Stan zdrowia populacji polskiej w wieku 20-74 lata w okresie 2003-2005. Podstawowe wyniki badania przekrojowego. Próba ogólnopolska. Instytut Kardiologii, Warszawa 2005.

20. Hooper L, Martin N, Abdelhamid A, Smith GD. Reduction in saturated fat intake for cardiovascular disease. Cochrane Database Syst Rev, 2015; 6: CD011737. doi: 10.1002/14651858. CD011737.

21. Poznańska A, Rabczenko D, Wojtyniak B. Wybrane czynniki ryzyka zdrowotnego związane ze stylem życia. W: Sytuacja zdrowotna ludności Polski i jej uwarunkowania. Wojtyniak B, Goryński P, Moskalewicz B (red). Narodowy Instytut Zdrowia Publicznego — Państwowy Zakład Higieny, Warszawa 2012; 287-304.

22. Kris-Etherton PM, Lichtenstein AH, Howard BV et al. Antioxidant vitamin supplements and cardiovascular disease. Circulation, 2004; 110: 637-641. doi: 10.1161/01.CIR.0000137822.39831.F1.

23. Dhonukshe-Rutten RA, de Vries JH, de Bree A et al. Dietary intake and status of folate and vitamin $B_{12}$ and their association with homocysteine and cardiovascular disease in European populations. Eur J Clin Nutr, 2009; 63: 18-30. doi: 10.1038/sj.ejcn.1602897.

24. Jankovic N, Geelen A, Streppel MT et al. Adherence to a healthy diet according to the World Health Organization guidelines and all-cause mortality in elderly adults from Europe and the United States. Am J Epidemiol, 2014; 180: 978-988. doi: 10.1093/aje/kwu229.

25. Stefler D, Pikhart H, Jankovic N et al. Healthy diet indicator and mortality in Eastern European populations: prospective evidence from the HAPIEE cohort. Eur J Clin Nutr, 2014; 68 : 1346-1352. doi: 10.1038/ejcn.2014.134.

26. Haveman-Nies A, Tucker KL, de Groot LC et al. Evaluation of dietary quality in relationship to nutritional and lifestyle factors in elderly people of the US Framingham Heart Study and the European SENECA study. Eur J Clin Nutr, 2001; 55: 870-880.

27. Frąckiewicz J, Roszkowski W, Brzozowska A, Kałuża J. Jakość diety a umieralność osób starszych zamieszkałych w rejonie warszawskim. Przegl Epidemiol, 2010; 64: 119-125.

28. Sahyoun N, Lin CL, Krall E. Nutritional status of the older adult is associated with dentition status. J Am Diet Assoc, 2003; 103: 61-66.

29. Kanauchi M, Kimiko Kanauchi K. Diet quality and adherence to a healthy diet in Japanese male workers with untreated hypertension. BMJ Open, 2015; 5: e008404. doi: 10.1136/bmjopen-2015-008404.

30. Kłosiewicz-Latoszek L, Szostak WB, Kopeć G et al. Wytyczne Polskiego Forum Profilaktyki Chorób Układu Krążenia dotyczące zasad prawidłowego żywienia. Wytyczne Polskiego Forum Profilaktyki Chorób Układu Krążenia — aktualizacja 2015. Podolec P, Kopeć G eds. Wydanie drugie. Polskie Forum Profilaktyki Chorób Układu Krążenia, Kraków, 2015.

Cite this article as: Waśkiewicz A, Szcześniewska D, Szostak-Węgierek D et al. Are dietary habits of the Polish population consistent with the recommendations for prevention of cardiovascular disease? — WOBASZ II project. Kardiol Pol, 2016; 74: 969-977. doi: 10.5603/KP.a2016.0003. 


\title{
Czy sposób żywienia polskiej populacji jest zgodny z rekomendacjami dotyczącymi profilaktyki chorób sercowo-naczyniowych? Badanie WOBASZ II
}

\author{
Anna Waśkiewicz ${ }^{1}$, Danuta Szcześniewska' ${ }^{1}$, Dorota Szostak-Węgierek², Magdalena Kwaśniewska³, \\ Andrzej Pająk ${ }^{4}$, Urszula Stepaniak ${ }^{4}$, Krystyna Kozakiewicz ${ }^{5}$, Andrzej Tykarski ${ }^{6}$, Tomasz Zdrojewski ${ }^{7}$, \\ Małgorzata E. Zujko8, Wojciech Drygas ${ }^{1,3}$ \\ 'Zakład Epidemiologii, Prewencji Chorób Układu Krążenia i Promocji Zdrowia, Instytut Kardiologii, Warszawa \\ 2Zakład Żywienia Człowieka, Warszawski Uniwersytet Medyczny, Warszawa \\ ${ }^{3}$ Katedra Medycyny Społecznej i Zapobiegawczej, Uniwersytet Medyczny, Łódź \\ ${ }^{4}$ Zakład Epidemiologii i Badań Populacyjnych, Instytut Zdrowia Publicznego, Wydział Nauk o Zdrowiu, Uniwersytet Jagielloński Collegium \\ Medicum, Kraków \\ 5III Klinika Kardiologii, Śląskie Centrum Chorób Serca, Śląski Uniwersytet Medyczny, Katowice \\ ${ }^{6}$ Katedra i Klinika Hipertensjologii, Angiologii i Chorób Wewnętrznych, Uniwersytet Medyczny im. Macinkowskiego w Poznaniu, Poznań \\ 7Zakład Prewencji i Dydaktyki, Klinika Nadciśnienia Tętniczego i Diabetologii, Gdański Uniwersytet Medyczny, Gdańsk \\ ¿Zakład Technologii i Towaroznawstwa Żywności, Uniwersytet Medyczny w Białymstoku, Bialystok
}

\section{Streszczenie}

Wstęp: Sposób żywienia wpływa na ryzyko sercowo-naczyniowe nie tylko bezpośrednio, ale również poprzez oddziaływanie na masę ciała, stężenia lipidów, ciśnienie tętnicze i ryzyko cukrzycy.

Cel: Celem pracy była ocena jakości żywienia dorosłych mieszkańców Polski, zarówno na poziomie poszczególnych składników odżywczych, jak i całościowo przy wykorzystaniu wskaźnika jakości diety (HDI). HDI odzwierciedla gradient ryzyka chorób sercowo-naczyniowych związanych z dietą.

Metody: W ramach II Wieloośrodkowego Ogólnopolskiego Badania Stanu Zdrowia Ludności (WOBASZ II) w latach 2013-2014 przebadano losową próbę mieszkańców Polski w wieku 20 lat i powyżej. Sposób żywienia oceniono u 5690 osób (2554 mężczyzn i 3136 kobiet). Zawartość w diecie wybranych składników odżywczych analizowano w odniesieniu do wartości zalecanego spożycia i zaleceń Światowej Organizacji Zdrowia. Wskaźnik jakości diety wyliczono na podstawie wielkości spożycia 7 składników (nasycone i wielonienasycone kwasy tłuszczowe, cholesterol pokarmowy, białko, błonnik, warzywa i owoce oraz wolny cukier). W przypadku zgodności z rekomendacją respondent za każdy czynnik żywieniowy uzyskiwał 1 punkt, w przypadku niezgodności - 0 punktów. Maksymalnie przy całkowicie prawidłowej diecie można było otrzymać 7 punktów.

Wyniki: Badana grupa charakteryzowała się wysokim udziałem osób z nadwagą i otyłością (69\% mężczyźni, 59\% kobiety), z hipercholesterolemią (odpowiednio 56\% vs. 55\%), nadciśnieniem tętniczym (50\% vs. 42\%) i cukrzycą (12\% vs. 10\%). Jednocześnie znaczny odsetek Polaków cechowały niewłaściwe nawyki żywieniowe. Dietę o niskiej zawartości tłuszczu i cholesterolu lub cukrzycową stosowało ok. 8\% respondentów, a odchudzającą — ok. 1\% Polaków. Dosalanie przy stole wcześniej już doprawionych potraw deklarowało 27\% mężczyzn i 18\% kobiet, a odpowiednio 56\% i 30\% osób spożywało mięso i wędliny z widocznym tłuszczem oraz drób z tłustą skórą. Racje pokarmowe dorosłej populacji polskiej były niezbilansowane pod względem zawartości niektórych składników odżywczych. Zalecenia dotyczące witaminy A, C, E, B1, B2,

\section{Adres do korespondencji:}

dr inż., adiunkt Anna Waśkiewicz, Zakład Epidemiologii, Prewencji Chorób Układu Krążenia i Promocji Zdrowia, Instytut Kardiologii, ul. Alpejska 42, 04-628 Warszawa, e-mail: awaskiewicz@ikard.pl

Praca wpłynęła: 14.10 .2015 r. Zaakceptowana do druku: 15.12 .2015 r.

Data publikacji AoP: 07.04.2016 r. 
B6, B12, białka, cholesterolu pokarmowego oraz warzyw i owoców realizowało 44-80\% respondentów. Rekomendowane spożycie tłuszczów, nasyconych i wielonienasyconych kwasów łłuszczowych, które istotnie oddziałują na stężenie lipidów, deklarowało jedynie 18-37\% badanych. Stwierdzono istotne niedobory w odniesieniu do folianów i składników mineralnych istotnych w profilaktyce nadciśnienia tętniczego. Prawidłowa zawartość w diecie folianów dotyczyła zaledwie $26 \%$ mężczyzn i 13\% kobiet, a magnezu, wapnia i potasu - 5-36\% respondentów.

Wnioski: 1. Znaczny odsetek dorosłych Polaków cechuje się niewłaściwymi zwyczajami żywieniowymi. 2. Większość polskiej populacji spożywa niezgodne z zaleceniami ilości nasyconych i wielonienasyconych kwasów tłuszczowych, a także błonnika. 3. Połowa dorosłej polskiej populacji spożywa niedostateczne ilości warzyw i owoców. 4. Spożycie witamin mających istotne znaczenie w profilaktyce chorób sercowo-naczyniowych jest w znacznym odsetku polskiej populacji niezadowalające. Dotyczy to zwłaszcza folianów. 5. W diecie dużej części populacji polskiej wystąpiły niedobory składników mineralnych istotnych w profilaktyce nadciśnienia tętniczego. 6. Sposób żywienia przeważającej części dorosłych Polaków znacznie odbiega od zaleceń Światowej Organizacji Zdrowia.

Słowa kluczowe: sposób żywienia, dieta, populacja polska, profilaktyka chorób sercowo-naczyniowych

Kardiol Pol 2016; 74, 9: 969-977 